\title{
LIBERDADE RELIGIOSA: UM ESTUDO COMPARATIVO DA JURISPRUDÊNCIA INTERNA E DOS SISTEMAS REGIONAIS EUROPEU E AMERICANO DE PROTEÇÃO DOS DIREITOS HUMANOS
}

\author{
Religious freedom: a comparitive study based on decisions from Brazil \\ and the European and American human rights systems
}

\section{Melina Alves Tostes}

Mestranda em Direito Constitucional pela PUC-SP. Procuradora da República.

Recebido em: 07.07.2012

Aprovado em: 01.09.2012

ÁreA do DIREITO: Constitucional; Internacional

RESUMO: Este trabalho irá analisar o direito à liberdade religiosa sob a perspectiva da jurisprudência do STF, da Corte Interamericana de Direitos Humanos e do Tribunal Europeu dos Direitos Humanos. Partindo da sua consagração como direito fundamental, será determinado os contornos e o alcance desse direito por meio da análise dos diplomas normativos que o preveem e pela forma como os litígios sobre ele vem sendo decididos. Será ainda observado a posição do Estado e seus deveres nesse campo, bem como a relação entre democracia e a liberdade de expressão com o direito à liberdade religiosa, além da presença de símbolos religiosos em espaços públicos. Com isso, objetiva-se delimitar o estabelecimento de parâmetros a serem seguidos em eventuais controvérsias sobre esse direito.
ABSTRACT: This article will study the extent of the right to religion freedom in the decisions of the Brazilian Supreme Court, the Interamerican Court of Human Rights, and the European Human Rights Curt, by comparing and analyzing different interpretations of freedom of religion from these various perspectives. It will also be discussed the position of the State in these matter, possible relations between freedom of religion with the democratic system and freedom of speech, and, the presence of religious symbols in public spaces. In the end, will hope to set some standards to be eventually followed in judicial cases involving the right to religious freedom. 
Palavras-chave: Liberdade religiosa - Tribunais internacionais - STF.
KEYWORDS: Religious freedom - International Courts - Brazil Supreme Court.

SumÁRIO: 1. Introdução - 2. Ordem juridica interna: análise da jurisprudência do STF - 3. Sistema Interamericano de Proteção aos Direitos Humanos - 4. Sistema Europeu de Proteção aos Direitos Humanos - 5. Considerações finais - 6. Bibliografia.

\section{INTRODUÇÃO}

Este artigo irá analisar o conteúdo do direito à liberdade religiosa sob a perspectiva da jurisprudência interna brasileira e dos Sistemas regionais Europeu e Americano de Proteção dos Direitos Humanos. ${ }^{1}$

O processo de internacionalização dos direitos humanos iniciou-se de forma gradativa, após a 2. ${ }^{a}$ Guerra Mundial, em reação aos horrores sofridos com a Guerra e o holocausto. Sob influência jusnaturalista, o homem passou a ter direitos a ele reconhecidos de forma inerente a sua condição de pessoa humana, imanentes a ele, independentemente de qualquer regulamentação estatal. O marco de tal processo evolutivo ocorre com a adoção em 1948, pelas Nações Unidas, da Declaração Universal de Direitos Humanos. ${ }^{2}$

Com a Declaração Universal de Direitos Humanos surge um Sistema Universal de Direitos Humanos. Vale ressaltar que esse instrumento trouxe tanto direitos civis e políticos (arts. $2 .^{\circ}$ a 21 ) como direitos econômicos, sociais e culturais (arts. 22 a 28). A Declaração Universal provocou um grande impacto nas Constituições, legislações e jurisprudências nacionais (CANÇADO Trindade, 2000, p. 30). Atualmente pode ser considerada fonte do direito internacional, na forma de costume, não tendo mais, apenas caráter de soft law. Posteriormente, com a complementação da Declaração, pelos Pactos de 1966, o Sistema Universal é composto, além da Declaração, pelo Pacto de Direitos Civis e Políticos e pelos Pactos de Direitos Econômicos, Sociais e Culturais, e seus Protocolos Facultativos. ${ }^{3}$

1. O Sistema Africano de Direitos Humanos não será objeto de estudo deste artigo.

2. O Brasil votou a favor da Declaração Universal de Direitos Humanos, na Assembleia Geral das Nações Unidas, em 10.12.1948, em que tal Declaração foi adotada e proclamada pela Assembleia.

3. O Brasil adotou ambos os pactos em 1992, pelos Decretos 591 e 592. 
Paralelamente ao surgimento do Sistema Universal de Direitos Humanos, a comunidade internacional assistiu ao nascimento de sistemas regionais de proteção. O Sistema Interamericano originou-se no âmbito da Organização dos Estados Americanos (OEA) e tem como bases legais principais a Carta da OEA e a Convenção Americana de Direitos Humanos. O Sistema Europeu surgiu dentro do Conselho da Europa, com a adoção da Convenção Europeia para a Proteção dos Direitos Humanos Liberdades Fundamentais. Por fim, o Sistema Africano desenvolveu-se no âmbito da Organização da Unidade Africana (hoje substituída pela União Africana), e tem como base normativa a Carta Africana dos Direitos Humanos e dos Povos - Banjul - Charta. Os dois primeiros sistemas serão discutidos em tópico próprio.

A liberdade religiosa está consagrada como direito inerente ao homem em todos os instrumentos internacionais de proteção aos direitos humanos mencionados. O art. XVIII da Declaração Universal afirma que toda pessoa tem direito à liberdade de religião. Delimita ainda que tal direito inclui a liberdade de mudar de religião ou crença e a liberdade manifestar essa religião ou crença, pelo ensino, pela prática, pelo culto e pela observância, isolada ou coletivamente, em público ou em particular. A redação do art. XVIII influenciou a redação dos arts. 9. ${ }^{\circ}$ e 12 da Convenção Europeia e da Convenção Americana, respectivamente, em que a liberdade religiosa encontra-se plenamente amparada. ${ }^{4}$

No estágio evolutivo atual em que se encontra a comunidade internacional, um país que não protege sua população contra violações graves de direitos humanos deve aceitar que a comunidade internacional assuma essa responsabilidade, uma vez que, as violações de direitos humanos não são mais um assunto interno dos Estados. A comunidade internacional tem um dever de ingerência (responsability to protect) no que concerne a garantia dos direitos humanos.

$\mathrm{Na}$ medida em que, a liberdade religiosa é reconhecida como direito fundamental do homem, em fontes normativas internacionais, consequentemente, passa a ser possível que sua violação possa ser perquirida em esfera internacional. Por outro lado, essa mesma previsão de seu conteúdo em tratados internacionais, quando assinados e ratificados por um determinado país, obriga que os magistrados desse país, conheçam e aplicam tais legislações, inclusive, confrontando atos e leis internas, com a legislação e jurisprudência internacional, em controle de convencionalidade.

4. A liberdade religiosa também encontra-se garantida no art. 8..$^{\circ}$ da Carta Africana dos Direitos Humanos e dos Povos. 
Dessa forma, para um estudo satisfatório do direito à liberdade religiosa, mister examinar como tal direito vem sendo aplicado, não apenas na ordem jurídica interna brasileira, notadamente, pelo STF; bem como, sua aplicação em tribunais internacionais. Nesse sentido, quer-se observar se há alguma influência entre tais esferas de proteção, bem como eventuais particularidades que ganha o conteúdo de tal direito, a depender do tribunal, no qual é apreciado.

\section{ORDEM JURÍDICA INTERNA: ANÁLISE DA JURISPRUDÊNCIA DO STF}

Com exceção da Constituição do Império de 1824, com a República, todas as demais Constituições brasileiras previram o direito à liberdade religiosa. A Constituição de 1988, em vigor, expressamente consagra, em seu rol de direitos e garantias fundamentais, no art..$^{\circ}$, VI, a inviolabilidade da liberdade de consciência e de crença, sendo assegurado o livre exercício dos cultos religiosos e garantidas, na forma da lei, a proteção aos cultos e as suas liturgias.

O inc. I do art. 19 da CF/1988 veda a qualquer ente federativo, estabelecer cultos religiosos ou igrejas, subvencioná-las, embaraçar-lhes o funcionamento ou manter com eles ou seus representantes relações de dependência ou aliança, ressalvada, na forma da lei, a colaboração de interesse público. Com isso, o Estado brasileiro não possui religião oficial, bem como, há uma separação entre religião e Estado. A laicidade do Estado representa uma garantia de mão dupla, tanto para as religiões que ficam livres de qualquer perseguição ou tratamento discriminatório pelo Estado, quanto para o cidadão, que tem respeitada a sua liberdade de crença, em um Estado pluralista. ${ }^{5}$ Outra consequência é o dever de neutralidade que o Estado deve ter em suas concepções religiosas. ${ }^{6}$

A liberdade de religião pode ser desdobrada em vários aspectos: liberdade de não ter religião, liberdade de mudar de religião, liberdade de expressar e propagar sua religião, liberdade de culto e direito à assistência religiosa. Pode ainda estar relacionado com outros direitos fundamentais, como o direito de reunião, associação, privacidade (WeingaRTNER NETo, 2011, p. 482). Um se-

5. Sarmento observa que: "o Estado Laico é garantia essencial para o exercício dos direitos humanos. Confundir Estado com religião implica a adoção oficial de dogmas incontestáveis que, ao impor uma moral única, inviabilizam qualquer projeto de sociedade pluralista, justa e democrática" (SARMEnto, 2010, p. 306).

6. Todavia, a Constituição de 1988 não permite inferir um modelo laicista entre Estado e religião, como o presente na França, o qual implica em uma relação de hostilidade do Estado perante a religião. 
gundo aspecto seria o direito da pessoa de orientar-se de acordo com as suas posições religiosas (BAStos, 2001, p. 499).

Passa-se a analisar algumas decisões proferidas pelo STF sobre o tema, tendo como parâmetro a Constituição de 1988.

A ADIn 2.566, de relatoria do Min. Nelson Jobim, julgada, em sede liminar, ${ }^{7}$ em 13.03.2002, teve como objeto o \& $1 .^{\circ}$ do art. $4 .^{\circ}$ da Lei 9.612/1998, o qual vedava: "o proselitismo de qualquer natureza na programação das emissoras de radiodifusão comunitária". O proselitismo se caracteriza pelo direito de procurar novos crentes, sendo um dos desdobramentos possíveis da liberdade religiosa.

Na presente ação, o Tribunal, em decisão não definitiva, entendeu que a vedação legal era constitucional e não violava a liberdade religiosa. Para a Corte, o dispositivo buscava evitar somente o desvirtuamento da radiodifusão comunitária, usada para fins a ela estranhos. O objetivo legal foi assim, considerado legítimo, posto que procurou afastar o uso desse meio de comunicação como instrumento de pregações religiosas, ou de qualquer sectarismos. Na ementa é ainda lembrada, a inexistência de direitos absolutos, ilimitados e ilimitáveis.

Interessante que a liberdade de religião ou crença também foi invocada como fundamento de defesa do dispositivo impugnado. Nesse sentido, o parecer da AGU afirma que diferente da livre manifestação do pensamento, a "atividade que se volta para converter pessoas, não apenas manifesta, mas transforma, modifica e altera valores, interferindo na liberdade de consciência ou de crença do interlocutor ou ouvinte". Dessa forma, cumpriria ao Poder Público zelar para que a radiodifusão como meio de comunicação "não se faça de forma ideológica, de defesa de dogmas, de persuasão em favor desta ou daquela ideia".

Vale ainda destacar, pela relação que estabelece entre o tema e o regime democrático, o voto divergente do Min. Celso de Mello. Para ele, em um contexto democrático, "temas de caráter teleológico ou concepções de índole filosófica - que busquem atribuir densidade teórica a ideias propagadas pelos seguidores de qualquer fé religiosa" estariam fora do alcance do poder censório do Estado, sob pena de violação da liberdade de crença e disseminação das mensagens inerentes às doutrinas confessionais.

Sobre o acórdão, necessário alertar, que a liberdade religiosa é uma espécie de liberdade de expressão. Ademais, um dos aspectos da liberdade de expressão é a liberdade de propagar ou difundir a expressão, e nessa esfera surge a importância dos meios de comunicação, como o serviço de radiodifusão. Sem

7. O mérito da ação ainda encontra-se pendente de julgamento. 
falar, na intrínseca relação entre liberdade de expressão como fundamento e mecanismo de controle essencial de garantia do regime democrático e do pluralismo de ideias. O proselitismo identifica-se como uma dimensão do direito à liberdade de crença ou religião, e por si só, deve ser respeitado pelo Estado, por estar relacionado com a liberdade de expressão e com a garantia de uma sociedade plural e democrática. Logo, a princípio, sua proibição em qualquer meio de comunicação deve ser visto com cautela, sob pena de representar uma indevida interferência estatal na pauta dos meios de comunicação, a despeito da decisão em sentido oposto do STF.

O segundo caso se deu no julgamento do RE 325.822-2/SP, em 18.12.2002, o qual refere-se ao tema do alcance das imunidades do templo de qualquer culto, prevista no art. 150, VI, $b$, da CF/1988. A imunidade em questão foi prevista no Texto Constitucional como forma de promover e assegurar o direito fundamental à liberdade de crença ou religião. Neste acórdão, o STF decidiu que a imunidade não estaria restrita aos templos em que são feitas as celebrações religiosas e às dependências que servem diretamente aos seus fins. Foi dada assim interpretação extensiva ao dispositivo constitucional, para que a imunidade alcance não somente os prédios destinados ao culto, mas também o patrimônio, a renda e os serviços relacionados com as finalidades essenciais das entidades religiosas. Observa-se assim, que a interpretação dada pelo Tribunal, reforçou a garantia à liberdade de crença ou religiosa, e permite um ambiente favorável ao crescimento e desenvolvimento das doutrinas religiosas.

O terceiro caso, representado pelo julgamento do STF, em AgRg na Suspensão de Tutela Antecipada 389/MG, esmiúça a relação entre Estado e religião. A decisão refere-se à possibilidade da participação de estudantes judeus no Exame Nacional do Ensino Médio (Enem), em data alternativa ao Shabat, com fundamento no direito fundamental à liberdade religiosa e no direito à educação. Todavia, o Tribunal entendeu que a designação de data alternativa para a realização dos exames feriria o princípio da isonomia, pois, acarretaria em privilégio para um determinado grupo religioso.

Foi lembrado no voto do Min. Gilmar Mendes, que o direito fundamental à liberdade religiosa impõe ao Estado dever de neutralidade diante do fenômeno religioso, vedada toda e qualquer atividade do ente público que favoreça determinada confissão religiosa em detrimento das demais. Ressaltou ainda, que o dever de neutralidade por parte do Estado não se confunde com a ideia de indiferença estatal, devendo o Estado, em alguns casos, adotar comportamentos positivos, com a finalidade de afastar barreiras ou sobrecargas que possam impedir ou dificultar determinadas opções em matéria de fé. Aduz ainda, que 
no caso, foi oferecida pelo Ministério da Educação, a possibilidade de os estudantes ficarem confinados e somente iniciarem o exame após o pôr do sol, o que seria mais compatível com o dever de neutralidade e tratamento isonômico ente os grupos religiosos, do que a designação de dia alternativo.

O voto do Min. Marco Aurélio, em sentido contrário ao vencedor, também deve ser aqui mencionado. Observa primeiro, que a obrigação de prestar exame naquela data não decorreu de lei, mas de ato administrativo. Ademais, qualquer solução dada ao impasse deveria levar em conta o "empréstimo de concretude maior às garantias constitucionais". Assim, seria melhor compatível com a Constituição e com a previsão da prestação alternativa, contida no art. 5. ${ }^{\circ}$, VIII, a designação da prova em dia útil, dia de atuação normal, tendo em conta os diversos segmentos da sociedade.

Não se pode negar que a solução dada pelo Min. Marco Aurélio é a que melhor assegura a liberdade religiosa, sem estabelecer qualquer tratamento discriminatório ou de privilégio a nenhum grupo religioso. O voto vencedor, cuja alternativa seria o confinamento por mais de sete horas dos alunos antes de iniciar o exame, certamente, prejudica o desempenho deles, constituindo-se em um tratamento mais gravoso e discriminatório a esse grupo religioso.

Sobre o tema, deve-se recordar que se encontra pendente de julgamento a ADIn 3901 e a ADIn 3.714, em que a Corte analisará com mais profundidade a questão e proferirá uma decisão definitiva. Na ADIn 3901 discute-se a constitucionalidade de leis paraenses que limitaram a realização de provas, concursos e avaliações escolares no período compreendido entre às 18 horas de sexta e às 18 horas do sábado subsequente, bem como o abono de faltas dos alunos, que comprovarem motivos religiosos para não comparecerem à instituição de ensino naquele período. Já a ADIn 3.714 refere-se à Lei do Estado de São Paulo, de conteúdo semelhante.

Por fim, em que pese não ser um caso colhido da jurisprudência do STF, deve ser destacadas, pela sua importância para o tema da liberdade religiosa e laicidade do Estado, a decisão proferida pelo Conselho Nacional de Justiça, em 2007, nos Pedidos de Providência n. 1.344, 1.345, 1.346 e 1.362, os quais tratavam da presença de símbolos religiosos, como crucifixos, em lugares públicos. O Conselho, com apenas um voto em sentido contrário, decidiu pela permanência de símbolos religiosos em repartições públicas, uma vez que, seriam símbolos meramente culturais e tradicionais, ou que expressariam a religiosidade do povo, sem comprometimento da liberdade de religião ou afronta ao Estado Laico. A fixação de crucifixo nos Tribunais representaria uma cultura ou tradição e não representaria uma forma de constrangimento ou discriminação com outros grupos religiosos. 
Percebe-se, pelos julgados acima, que o conteúdo do direito à liberdade religiosa, no direito interno, está em permanente construção, e a relação entre religião e Estado ainda não está plenamente delimitada, sendo ainda um tema complexo e controvertido na jurisprudência.

\section{Sistema Interamericano de Proteção aos Direitos Humanos}

Consoante dito, o Sistema Interamericano de Proteção de Direitos Humanos tem como base normativa principal a Convenção Americana de Diretos Humanos - Pacto de San José da Costa Rica. Esse tratado prevê os dois órgãos responsáveis pela implementação do sistema: a Comissão Interamericana de Direitos Humanos ${ }^{8}$ e a Corte Interamericana de Direitos Humanos.

Em que pese a Convenção ter sido adotada em 1967 e a Corte criada em 1978, o Brasil apenas ratificou a Convenção em 1992, e somente aceitou a competência da Corte em 1998.

A Corte Interamericana de Direitos Humanos nasceu inspirada na Corte Europeia de Direitos Humanos, porém, foram surgindo diferenças entre ambas pela estrutura do sistema, condições financeiras e orçamentárias, e contexto político em que cada uma se insere. A Corte Interamericana não tem caráter permanente, conta com poucos juízes, não possui efetivos mecanismos de cumprimento de suas decisões e não aceita petições individuais. Com isso, sua jurisprudência acaba sendo bem mais escassa, em comparação com o modelo europeu, não obstante em franca expansão. Como exemplo, apenas um caso já examinado e julgado pela Corte (A última tentação de Cristo v. Chile) tem como objeto o art. 12 da Convenção, que trata da liberdade religiosa.

$\mathrm{O}$ art. 12 da Convenção estabelece um amplo alcance para liberdade de consciência e de religião. Nesse sentido, segue a Declaração Universal, ao prescrever que toda pessoa tem direito à liberdade de consciência e religião, o que implica na liberdade de conservar a sua religião ou suas crenças ou de mudar de religião, bem como a liberdade de professá-la e divulgá-la, individual ou coletivamente, de forma pública ou privada. Todavia, o artigo ainda contempla que ninguém pode ser objeto de medidas restritivas, que possam limitar sua liberdade de conservar ou de mudar de religião ou crença, sendo que a even-

8. A Comissão Americana de Direitos Humanos começa a funcionar em 1959 como órgão autônomo da OEA, com a função de promover a Declaração Americana dos Direitos do Homem (1948) e, futuramente, a Convenção Americana de Direitos Humanos (1967). Em 1965, a Comissão passa a poder aceitar petições individuais. Tem sede em Washington D.C., nos EUA. 
tual limitação possível ao direito em questão deve estar prevista em lei, além de fundamentar-se na proteção a segurança, ordem, saúde, moral pública, ou direitos e liberdades de outras pessoas. Inova ainda ao assegurar que os pais ou tutores tenham garantido o direito a que seus filhos e pupilos recebam educação religiosa e moral de acordo com suas próprias convicções.

Considerando o conteúdo amplo da liberdade religiosa previsto na Convenção, passa-se agora a análise do Caso A última tentação de Cristo v. Chile, único julgado da Corte sobre o tema, em 05.02.2001. ${ }^{9}$ O caso faz relação entre liberdade religiosa e liberdade de expressão e versa sobre a proibição da veiculação do filme A última tentação de Cristo no Chile.

A Comissão Interamericana de Direitos Humanos alegou, que a proibição do acesso a trabalho de arte com índice religioso foi baseada em uma série das considerações que interferem de maneira imprópria com a liberdade de consciência e de religião presumida das vítimas e dos demais habitantes do Chile, o que viola o art. 12 da Convenção.

Para a Comissão, o reconhecimento da liberdade de consciência é baseado no mesmo reconhecimento do ser humano como ser racional e independente. A proteção do direito a essa liberdade é a base do pluralismo necessário para o coexistência em uma sociedade democrática que, como toda a sociedade, encontra-se integrada por indivíduos de convicções e de crenças variadas.

De acordo com o art. 12 da Convenção, "o Estado deve tomar as medidas necessárias e proporcionais para que as pessoas que professam publicamente suas crenças, conduzam seus ritos e levem a cabo seu proselitismo dentro dos limites que razoavelmente podem ser impostos em uma sociedade democrática". Esta norma exige a abstenção do Estado em interferir de qualquer modo com a adoção, a manutenção ou a mudança das convicções pessoais religiosas ou de outro caráter. O Estado não deve utilizar seu poder para proteger a consciência de determinados cidadãos.

A Comissão aponta que a interferência do Estado afetou aqueles que mantêm crenças que se relacionam com o conteúdo religioso da película A última tentação de Cristo, já que se veem impedidos de exercitar o direito à liberdade de consciência, ao não poder ver a película e formar a sua própria opinião sobre ideias nela expressada. Também atingiu àqueles que pertencem a outros credos ou não têm convicções religiosas, já que, privilegiou um credo, em prejuízo do acesso livre à informação do resto das pessoas que quem teriam o direito a assistir e formar a sua opinião sobre a obra. A proibição da exibição

9. Disponível em: [www.corteidh.or.cr/docs/casos/articulos/seriec_73_esp.pdf]. 
do filme pelo Tribunal, na opinião da Comissão, constituiu uma interferência ilegítima ao direito de manter ou mudar as próprias convicções ou crenças e afetou, por si só, o direito a liberdade de consciência das pessoas supostamente prejudicadas pela proibição.

Por outro lado, ao julgar se houve violação ao art. 12 da Convenção, a Corte, primeiro enunciou, que de acordo com o art. 12, o direito à liberdade de consciência e religião permite que os povos conservem, mudem, professem e divulguem sua religião ou sua opinião. Este direito é um dos fundamentos da sociedade democrática. Em sua dimensão religiosa, constitui um elemento transcendental na proteção das convicções dos crentes e em sua forma de vida. Fez, assim como a Comissão, relação entre liberdade religiosa e regime democrático.

No caso em pauta, não obstante, a Corte Interamericana entendeu não existir prova alguma, que comprove a violação a qualquer das liberdades consagradas no art. 12 da Convenção. De fato, compreende a Corte que a proibição da exibição da película $A$ última tentação de Cristo não privou ou minorou a nenhuma pessoa seu direito de conservar, mudar, professar ou divulgar, com liberdade absoluta, sua religião ou crença.

A Corte então, a despeito da opinião da Comissão, decidiu que o Estado não violou o direito à liberdade de consciência e religião proclamado no art. 12 da Convenção americana, em que pese ter condenado o Estado chileno, pela violação à liberdade de expressão - art. 13 da Convenção e obrigou o Estado a permitir a divulgação do filme.

A decisão pode talvez indicar uma leitura mais estrita do conteúdo desse direito pela Corte. A esse respeito, vale lembrar, que como a própria Corte afirma em suas decisões, os direitos têm uma interpretação uniforme e essa interpretação se impõe mesmo aos Estados Nacionais não partes da decisão, o que faz com que esse julgado sirva de orientação aos demais Estados signatários, em casos semelhantes. Por outro lado, com apenas um único julgado sobre o tema, não é possível inferir, de forma, segura, o entendimento da Corte quanto ao conteúdo e limites do direito à liberdade de crença e religião.

\section{Sistema Europeu de Proteção aos Direitos Humanos}

O Sistema Europeu encontra-se em estágio bem mais avançado que os demais. Mudanças legislativas em 1993 impuseram que, para que um país seja integrante da União Europeia é necessário que aceite, previamente, a Convenção Europeia de Direitos Humanos e a competência do Tribunal Europeu de Direitos Humanos. Com isso, o Sistema Europeu adquiriu plena vigência. 
Outra mudança que aumentou consideravelmente o alcance e impacto desse sistema ocorreu com o Protocolo 11, que permitiu que os indivíduos, peticionassem diretamente à Corte. Ademais, o Sistema Europeu, diferentemente do americano, possui mecanismos de pressão e efetivação, que obrigam os Estados a cumprirem as decisões da Corte, quando condenados.

A liberdade religiosa está consagrada no art. 9. ${ }^{\circ}$ da Convenção Europeia de Direitos Humanos, a qual declara que qualquer pessoa tem direito à liberdade de pensamento, de consciência e de religião; este direito implica a liberdade de mudar de religião ou de crença, assim como a liberdade de manifestar a sua religião ou a sua crença, individual ou coletivamente, em público e em privado, por meio do culto, do ensino, de práticas e da celebração de ritos. Declara ainda que a liberdade de manifestar a sua religião ou convicções, individual ou coletivamente, não pode ser objeto de outras restrições senão as que, previstas na lei, constituírem disposições necessárias, numa sociedade democrática, à segurança pública, à proteção da ordem, da saúde e moral públicas, ou à proteção dos direitos e liberdades de outrem. Percebe-se assim, que a redação do dispositivo europeu, em muito se assemelha, com o americano.

O Tribunal Europeu de Direitos Humanos possui uma numerosa jurisprudência sobre eventuais violações ao art. 9. ${ }^{\circ}$ da Convenção Europeia de Direitos Humanos, porém apenas dois serão aqui tratados, por demonstrarem relevantes paradigmas sobre o tema.

Um dos casos dignos de análise, pela similaridade com o caso A última tentação de Cristo v. Chile julgado pela Corte Interamericana, é o caso Otto-Preminger-Institut v. Áustria, julgado pelo Tribunal Europeu de Direitos Humanos, em 23.08.2004. ${ }^{10}$

O caso refere-se à suposta violação à liberdade de expressão consagrada no art. 10 da Convenção, pela apreensão e confisco do filme Das Liebeskonzil (Council in Heaven), sob o fundamento do direito à religião das pessoas. O filme retratava de maneira negativa e caricatural a religião católica, a figura de Jesus e da Virgem Maria.

Ao julgar, o Tribunal, primeiro enuncia que para avaliar se a interferência estatal na liberdade de expressão foi legítima, deve-se examinar se foram cumpridos os requisitos para a limitação de tal direito, prevista no § 2. ${ }^{\circ}$ do art. 10. Os requisitos são: (a) restrição prevista em lei; (b) finalidade legítima da restrição; e (c) necessidade da restrição em uma sociedade democrática.

10. Disponível em: [www.iidh.ed.cr/comunidades/libertadexpresion/docs/le_europeo/ otto\%20preminger-institut\%20v.\%20austria.htm]. 
Sobre a existência de uma lei prevendo uma restrição à liberdade de expressão, o Tribunal constatou que a liberdade religiosa está consagrada no art. 14 da Constituição da Áustria, bem como, que a seção 188 do CP austríaco reprime condutas que ataquem objetos sagrados para alguma religião e que possam causar uma justificada indignação nos seguidores dessa religião. Não cabendo ao Tribunal Internacional discutir a interpretação do dispositivo interno feita pela autoridade nacional. Considerou que este requisito foi cumprido.

O segundo passo a avaliar, seria se a restrição à liberdade de expressão decorreu de uma das finalidades legítimas previstas na Convenção: segurança pública, proteção da ordem, da saúde e moral públicas, ou proteção dos direitos e liberdades de outrem. No caso, o governo austríaco alegou a proteção de outros direitos, em especial, o direito aos sentimentos religiosos dos outros e a prevenção de uma desordem pública para justificar a restrição.

O Tribunal asseverou que a liberdade de pensamento, consciência e religião consagrada no art. 9. ${ }^{\circ}$ da Convenção é um dos fundamentos de uma sociedade democrática. A liberdade religiosa é um dos elementos vitais para a identidade dos crentes, e sua concepção de vida.

O Tribunal ainda ressaltou, que aquele que escolhe manifestar sua liberdade de religião, seja pertencente de um grupo religioso minoritário ou majoritário, não pode esperar estar livre de críticas. Pelo contrário, deve tolerar e aceitar que outros neguem sua religião e, até mesmo, a propaganda de outras doutrinas religiosas hostis a sua. Contudo, a maneira em que uma doutrina religiosa pode ser confrontada ou negada é suscetível de encadear à responsabilidade do Estado, em especial, a responsabilidade estatal de assegurar um ambiente pacífico e favorável ao direito à liberdade religiosa de todos os grupos ou doutrinas religiosas. Observa que em casos extremos, um método agressivo ou exorbitante de negar ou confrontar determinada religião pode acabar fazendo com que o grupo que a ela pertence, fique inibido de expressá-la. Por isso, o Estado pode, legitimamente, se considerar necessário, tomar medidas destinadas a reprimir condutas, inclusive divulgação de ideias e informações, julgadas incompatíveis com o respeito à liberdade de pensamento, consciência e religião.

Em seguida, anotou que o respeito aos objetos de veneração e símbolos sagrados religiosos também está dentro da esfera de proteção do art. 9.. Quando esses objetos ou símbolos são retratados de forma provocativa ou maliciosa, violam o espírito de tolerância que deve permear uma sociedade democrática. A Convenção deve ser vista como um todo, porquanto, a interpretação e aplicação do art. 10 - liberdade de expressão deve estar em harmonia com a essência da Convenção. 
No caso austríaco, o Tribunal europeu entendeu que as medidas tomadas pelo governo, com fundamento no art. 188 do CP austríaco, seguiram o propósito de proteger o direito dos cidadãos de não serem insultados em seus sentimentos religiosos e crenças, pela liberdade de expressão de outras pessoas. Logo, conclui que a finalidade declarada pelo Estado austríaco, "proteção dos direitos de outros", para a restrição à liberdade de expressão foi legítima, cumprido assim o segundo requisito.

Parte, em seguida, para a análise do terceiro e último requisito, ou seja, saber se a restrição à liberdade de expressão era necessária em uma sociedade democrática.

A liberdade de expressão é ressaltada como um dos fundamentos de uma sociedade democrática, uma das condições básica para o progresso e desenvolvimento de todos. O alcance desse direito inclui as informações ou ideias tidas como ofensivas ou capazes de chocar ou causar distúrbios para o Estado ou para um setor da população. Essa situação faz parte de um contexto plural, de tolerância e diversidade, sem o qual não há democracia.

Porém, o exercício da liberdade de expressão é acompanhado de deveres e responsabilidades. Dentre elas, em um contexto de crenças e tradições religiosas, pode-se legitimamente incluir uma obrigação de evitar, o máximo possível, expressões que tragam agressões gratuitas aos outros ou que infringem direitos de outros, e que, portanto, não contribuem de qualquer forma para o debate público capaz de enriquecer o progresso humano.

Pode assim, ser considerado necessário em determinadas sociedades democráticas, sancionar ou até prevenir para evitar ataques impróprios e indevidos a objetos e símbolos considerados sagrados por uma religião, desde que seja uma imposição proporcional a finalidade a ser alcançada.

O Tribunal esclarece que a solução da questão envolve um aspecto moral, não sendo possível distinguir, de maneira uniforme na Europa, uma única solução para a o significado da religião em cada sociedade. Até mesmo dentro de um mesmo país, a forma com que a sociedade lida com a religião pode variar. Logo, uma resposta definitiva sobre o que seria uma interferência legítima na liberdade de expressão quando em contraponto com o sentimento religioso dos demais não pode ser dada. Conclui assim, existir uma margem de apreciação deixada às autoridades locais, para avaliar a necessidade e o alcance de eventual restrição à liberdade de expressão, quando em contraponto com a liberdade religiosa. A margem de apreciação não é ilimitada, como bem lembra o Tribunal, mas deve estar de acordo com a Convenção e deve variar de acordo com as circunstâncias do caso.

Ao decidir, o Tribunal levou em conta que a quase a totalidade da população do local seguia a religião católica. As autoridades, ao apreenderem e confisca- 
rem o filme, atuaram para assegurar a paz religiosa no local. Foi considerado ainda, que as autoridades locais estão mais bem habilitadas para avaliar a necessidade de se tomar qualquer medida de restrição diante da situação exposta. O que o Tribunal Internacional poderia julgar seria eventual extrapolação da margem de apreciação do governo local, o que foi considerado não ocorrido no caso.

A decisão do Tribunal europeu conclui assim, que não houve, pela conduta do governo austríaco, violação à liberdade de expressão prevista no art. 10 da Convenção, ao apreender e confiscar o filme Das Liebeskonzil, uma vez que a restrição a esse direito ocorreu de acordo com a Convenção, isto é, estava prevista em lei, tinha como objetivo a finalidade legítima de proteger o direito à liberdade religiosa e era necessária naquela determinada sociedade democrática.

Esse caso representa um paradigma sobre a relação entre liberdade religiosa e liberdade de expressão. Passa-se, a seguir, para a análise da segunda decisão.

O caso de maior repercussão sobre o tema foi, sem dúvida, o caso Lautsi v. Itália, sobre a presença de crucifixos nas escolas públicas italianas. Primeiramente, o caso foi admitido pela 2. ${ }^{a}$ Câmara do Tribunal europeu, que em 03.11.2009, julgou o caso. ${ }^{11}$

A 2. ${ }^{a}$ Câmara observou que o direito fundamental à educação compreende o direito dos pais de terem respeitadas suas convicções religiosas e filosóficas. O respeito para com as convicções dos pais deve ser possível no contexto da instrução capaz de assegurar um ambiente escolar aberto, que incentive a inclusão melhor que a exclusão, independentemente do contexto social dos alunos, das suas crenças religiosas ou origens étnicas. As escolas não devem ser arena para atividades ou proselitismo; devem ser um lugar de encontro para as diferentes religiões e convicções filosóficas, onde os alunos possam ter conhecimento sobre seus respectivos pensamentos e tradições. O respeito às convicções religiosas dos pais e às crenças das crianças implica ainda na liberdade de ter ou não uma religião, ambas protegidas pelo art. 9. ${ }^{\circ}$ da Convenção.

Ressalta a 2. ${ }^{2}$ Câmara que, o Estado tem o dever de neutralidade e imparcialidade, o qual é incompatível com qualquer tipo de poder Estatal de conferir legitimidade para determinada convicção religiosa ou a forma de expressar certa religião. No contexto de um ambiente de ensino, a neutralidade deve garantir o pluralismo. Isso faz com que o Estado tenha o dever de se restringir de impor qualquer tipo de crença, ainda que de forma indireta, em lugares em que

11. Disponível em: [www.cirdi.org/wp/wp-content/uploads/2011/05/lautsi-vs-italia-2009.pdf]. 
as pessoas são dependentes ou são particularmente vulneráveis. A educação infantil é, nesse sentido, uma área sensível em que o poder do Estado pode ser imposto em pessoas em que ainda não possuem senso crítico que permitiria que elas separassem a mensagem de uma preferência estatal por uma determinada religião.

Na opinião da Câmara, o símbolo do crucifixo tem de fato inúmeros significados, porém, dentre esses, o significado religioso é o que predomina. Considera assim, que a presença do crucifixo em salas de aula ultrapassa o uso de símbolos em um específico contexto histórico. Ademais, são incapazes de passarem despercebidos nesses ambientes. No contexto do ensino público, são necessariamente percebidos como uma parte integral do ambiente escolar e podem, portanto, serem tidos como poderosos símbolos externos.

Foi ainda apontado na decisão, que o Estado tem o dever de assegurar um ambiente de neutralidade confessional no sistema público de ensino, em que a matrícula é obrigatória, independentemente da religião, em, onde, deve ser insculpido nos alunos a habilidade ou senso crítico. A Seção não conseguiu compreender, como a exposição em uma sala de aula pública de um símbolo que remete ao catolicismo, pode auxiliar para o pluralismo educacional, o qual é essencial para a preservação de uma sociedade democrática. Considerou ainda, que a exposição compulsória do símbolo de uma determinada religião restringe o direito dos pais de educar seus filhos em conformidade com as suas próprias convicções e o direito das crianças em idade escolar de acreditar ou não.

Com fundamento nos argumentos acima, a 2. ${ }^{a}$ Câmara do Tribunal europeu consignou, de forma unânime, que a presença de crucifixos em escolas públicas viola o art. 9. ${ }^{\circ}$ da Convenção. Todavia, a Itália recorreu de tal decisão ao Plenário da Corte Europeia de Direitos Humanos. Dez Estados-membros do Conselho Europeu pediram a intervenção nesse processo como amicus curiae, o que contribui para a politização do caso. O Pleno, na data de 18.03.2001, em um procedimento pouco comum, acabou por revogar, a decisão proferida de forma unânime pela $2 .^{\text {a }}$ Seção. ${ }^{12}$

O Pleno considerou que de fato, o Estado tem o dever de neutralidade e independência com as diversas religiões, devendo assegurar um ambiente harmônico e de tolerância entre as diversas religiões em uma sociedade democrática. Contudo, os Estados-partes da Convenção possuem uma ampla margem de consideração a respeito dos passos que devem ser tomados para que o art. 9. ${ }^{\circ}$ dessa mesma Convenção seja obedecido.

12. Disponível em: [www.echr.coe.int/echr/resources/hudoc/lautsi_and_others_v_italy. pdf]. 
Segundo o Pleno, o Tribunal Europeu de Direitos Humanos não pode imiscuir-se nessas questões, pois as respostas podem legitimamente variar de acordo com o país e a época. Ao Estado é vedado perseguir uma finalidade de doutrinamento, que se traduziria em um desrespeito às crenças e convicções dos pais a respeito da educação de seus filhos. Este é o limite que os Estados não podem atravessar. Por outro lado, considera que o crucifixo é, sobretudo, um símbolo religioso. Sem embargo, não haverá evidência reveladora de que um símbolo religioso em uma sala de aula possa ter alguma influência sobre os alunos.

Mesmo assim, o Pleno declarou que a organização do ambiente escolar é uma questão das autoridades públicas, a educação é uma função assumida pelo Estado. Nesta ordem de ideias, a decisão de ter crucifixos expostos nas paredes das salas de aulas das escolas públicas, forma parte das funções assumidas pelo Estado.

Observa-se, que no caso Lautsi vs. Itália, a presença dos crucifixos nas escolas públicas adquiriu uma conotação política e religiosa. A decisão do Pleno não analisou se houve uma violação ao art. 9. ${ }^{\circ}$ da Convenção, pois consignou que a matéria seria de competência interna, na qual o Estado possuiria grande margem de apreciação e o Tribunal não poderia fornecer uma resposta adequada ao caso, que seria variável conforme o tempo e o país. Não obstante, tal decisão não se encontra livre de críticas, na medida em que, não conferiu a máxima eficácia ao art. 9. ${ }^{\circ}$ da Convenção, como ocorreu na decisão proferida pela 2. ${ }^{a}$ Câmara.

\section{CONSIDERAÇõES FINAIS}

1. Com a internacionalização dos direitos humanos, um país que não proteger sua população contra graves violações de direitos humanos está sujeito a interferência da comunidade internacional, que tem um dever de ingerência, e uma responsabilidade de proteção sobre o tema.

2. Com a assinatura e ratificação pelo Brasil de tratados internacionais de direitos humanos, os magistrados internos passaram a ter o dever de conhecer e aplicar os dispositivos internacionais sobre o tema, bem como, considerar a jurisprudência dos tribunais internacionais. Os dispositivos do direito interno estão sujeitos a controle de convencionalidade pelo juiz.

3. A liberdade religiosa está consagrada no âmbito do direito interno, pela Constituição Federal de 1988, e em instrumentos internacionais de proteção dos direitos humanos. O conteúdo desse direito na Declaração Universal de Direitos Humanos inspirou a redação da Convenção Americana e Europeia de Direitos Humanos, ao prever que esse direito inclui a liberdade de mudar de religião ou crença, a liberdade de manifestá-la, isolada ou coletivamente, em público ou par- 
ticular. No âmbito regional, os tratados ainda trouxeram a previsão de que a restrição a esse direito deve vir prescrita em lei, e fundamentar-se na proteção à segurança, ordem, saúde e moral públicas, ou direitos e liberdades de outras pessoas.

4. Na jurisprudência internacional é destacada a relação entre a liberdade religiosa e regime democrático. A Corte Americana de Proteção aos Direitos Humanos afirma que a proteção à liberdade religiosa é a base do pluralismo necessário para a coexistência em uma sociedade democrática. Já o Tribunal europeu afirma que essa liberdade constitui um dos fundamentos da sociedade democrática, a própria Convenção Europeia dispõe que a restrição à liberdade religiosa somente se justifica quando necessária em uma sociedade democrática. Contudo, a relação entre liberdade religiosa e democracia não é tratada pela jurisprudência interna brasileira.

5. A liberdade religiosa também relaciona-se com a liberdade de expressão. Primeiro, porque decorrente dela, segundo porque, pode justificar sua restrição em determinados casos. Um conflito entre liberdade religiosa e liberdade de expressão deve ser resolvido à luz do caso concreto, levando em consideração a relação que a sociedade possui com a religião. Por isso que nesse campo, uma única resposta é impossível, o que pode ser demonstrado pelas decisões conflitantes na ADIn 2.566, julgada, em sede liminar, pelo STF; no caso A última tentação de Cristo v. Chile, julgado pela Corte Interamericana de Direitos Humanos e no caso Otto-Preminger Institut v. Austria, julgado pelo Tribunal Europeu de Direitos Humanos. Porém, os três requisitos a serem cumpridos, para que a liberdade de expressão possa ser restringida, utilizados pelo Tribunal Europeu, devem ser seguidos.

6. O Estado tem um dever de neutralidade e independência com os grupos religiosos, esse aspecto é destacado tanto no âmbito interno (AgRg na Suspensão de Tutela Antecipada 389/MG e RE 352.822-2), como no âmbito internacional, desdobrando-se em uma obrigação de não fazer. Porém, o Tribunal Europeu de Direitos Humanos (caso Otto-Preminger Institut vs. Austria) vai além, e impõe um conteúdo positivo a esse dever, ao dispor que o Estado tem a responsabilidade de assegurar um ambiente pacífico e favorável ao direito à liberdade de crença de todos os grupos ou doutrinas religiosas, inclusive com a possibilidade de tomar medidas restritivas, como a proibição de divulgação de ideias e informações meramente ofensivas a determinadas crenças ou sancionar ataques impróprios aos símbolos considerados sagrados por alguma religião.

7. A presença de crucifixos em lugares públicos também insere-se no âmbito da relação entre Estado e religião. O Conselho Nacional de Justiça decidiu pela permanência de tais símbolos, por terem valor cultural ou tradicional muito mais que religioso. Já o Tribunal Europeu de Direitos Humanos entendeu que, 
embora o crucifixo possua, de fato, inúmeros significados, o símbolo religioso é o que prevalece ou predomina. Porém, a legitimidade de sua presença em lugares públicos, em especial, escolas públicas, encontra-se dentro da margem de apreciação de cada Estado.

8. O conteúdo do direito à liberdade religiosa, em que pese vem sendo ampliado, ainda está em permanente construção, tanto no âmbito interno, quanto no âmbito internacional. A relação entre Estado e religião sempre terá uma maior complexidade, haja vista que, a responsabilidade e o papel do Estado devem continuamente levar em consideração as circunstâncias do local, e a forma com que a sua sociedade relaciona-se com a religião, o que impede a importação de soluções definitivas, prontas ou acabadas. Todavia, sem dúvida, o magistrado brasileiro, tem muito a ganhar ao ter em conta a jurisprudência internacional sobre o tema, não podendo mais, no estágio atual, desconhecê-la.

\section{BIBLIOGRAFIA}

Bastos, Celso Seixas Ribeiro. Direito de recusa de pacientes submetidos a tratamento terapêutico às transfusões de sangue, por razões científicas e convicções religiosas. Revista dos Tribunais. vol. 787. p. 493. São Paulo: Ed. RT, maio 2001.

Cançado Trindade, Antônio Augusto. A proteção internacional dos direitos humanos e o Brasil. 2. ed. Brasília: Universidade de Brasília, 2000. Edições Humanidade, Série Prometeu.

Sarmento, Daniel. Livres e iguais: estudos de direito constitucional. Rio de Janeiro: Lumen Juris, 2010.

Weingartner Neto, Jaime. Liberdade religiosa na jurisprudência do STF. In: Sarmento, Daniel; SARlet, Ingo Wolfgang. Direitos fundamentais no Supremo Tribunal Federal: balanço e crítica. Rio de Janeiro: Lumen Juris, 2011.

\section{Pesouisas do Editorial}

\section{Veja também Doutrina}

- A liberdade religiosa nas Constituições do Brasil, de Arnaldo Sampaio de Moraes Godoy - $R D C l 34 / 155 ;$

- Exercício da liberdade religiosa, de Maria Luiza Whately Barretto - RDCl 14/249; e

- Solucionando o conflito entre o direito à imagem e a liberdade de expressão: a contribuição da jurisprudência da Corte Interamericana de Direitos Humanos, de Edson Beas Rodrigues Jr. - RT 905/88. 